\title{
From the middle stratosphere to the surface, using nitrous oxide to constrain the stratosphere-troposphere exchange of ozone
}

\author{
Daniel J. Ruiz ${ }^{1}$ and Michael J. Prather ${ }^{1}$ \\ ${ }^{1}$ Department of Earth System Science, University of California, Irvine, CA 92697-3100, USA \\ Correspondence to: Daniel J. Ruiz (djruiz@uci.edu)
}

\begin{abstract}
Stratosphere-troposphere exchange (STE) is an important source of tropospheric ozone, affecting all of atmospheric chemistry, climate, and air quality. Observations and the theory of tracer correlations provide only coarse $( \pm 20 \%)$ global-mean constraints. For fluxes resolved by latitude and month we rely on global chemistry-transport models (CTMs), and unfortunately, these results diverge greatly. Overall, we lack guidance from model-measurement metrics that inform us about processes and patterns related to the STE flux of ozone. In this work, we use modeled tracers $\left(\mathrm{N}_{2} \mathrm{O}, \mathrm{CFCl}_{3}\right)$ whose distributions and budgets can be constrained by satellite and surface observations, allowing us to follow stratospheric signals across the tropopause. The satellite derived photochemical loss of $\mathrm{N}_{2} \mathrm{O}$ on annual and quasi-biennial cycles can be matched by the models. The STE flux of $\mathrm{N}_{2} \mathrm{O}$-depleted air in our CTM drives surface variability that closely matches observed fluctuations on both annual and quasi-biennial cycles, confirming the modeled flux. The observed tracer correlations between $\mathrm{N}_{2} \mathrm{O}$ and $\mathrm{O}_{3}$ in the lowermost stratosphere provide a seasonal, hemispheric scaling of the $\mathrm{N}_{2} \mathrm{O}$ flux to that of $\mathrm{O}_{3}$. For $\mathrm{N}_{2} \mathrm{O}$ and $\mathrm{CFCl}_{3}$, we model greater southern hemispheric STE fluxes, a result supported by some metrics, but counter to prevailing theory of wave-driven stratospheric circulation. The STE flux of $\mathrm{O}_{3}$, however, is predominantly northern hemispheric, but observational constraints show that this is only caused by the Antarctic ozone hole. Here we show that metrics founded on observations can better constrain the $\mathrm{STE} \mathrm{O}_{3}$ flux which will help guide future model assessments.
\end{abstract}

\section{Introduction \& Background}

The influx of stratospheric ozone $\left(\mathrm{O}_{3}\right)$ into the troposphere affects its distribution, variability, lifetime, and thus its role in driving climate change and surface air pollution. The net stratosphere-to-troposphere exchange (STE) flux of $\mathrm{O}_{3}$ has a regular seasonal cycle in each hemisphere that is an important part of the tropospheric $\mathrm{O}_{3}$ budget (Stohl et al., 2003). Such fluxes are not directly observable, and we rely on observational estimates using trace-gas ratios in the stratosphere (McLinden et al., 2000; Murphy \& Fahey, 1994) or dynamical calculations using measured/modeled winds and $\mathrm{O}_{3}$ abundances (Gettleman et al., 1997; M. A. Olsen et al., 2004; Yang et al., 2016). The uncertainty in these estimates does not effectively constrain the wide range of the models being used to project future ozone (Young et al., 2013, 2018). Here we present the case for using the observed variations in nitrous oxide $\left(\mathrm{N}_{2} \mathrm{O}\right)$ from the middle stratosphere through to the surface in order to constrain the STE flux of $\mathrm{O}_{3}$. A similar case has been made for the radionuclide ${ }^{7} \mathrm{Be}$ (Liu et al., 2016), but $\mathrm{N}_{2} \mathrm{O}$ has a wealth of model-observation metrics on hemispheric, seasonal, and interannual scales that constrains its STE flux very well. 
Ozone-rich stratospheric air has been photochemically aged and is depleted in trace gases such as $\mathrm{N}_{2} \mathrm{O}$ and chlorofluorocarbons (CFCs). For these trace gases, the overall circulation from tropospheric sources to stratospheric destruction and back is part of the lifecycle that maintains their global abundance (Holton, 1990). For $\mathrm{N}_{2} \mathrm{O}$ and CFCs, this cycle of (i) loss in the middle to upper stratosphere, (ii) transport to the lowermost stratosphere (Holton et al., 1995), and then (iii) influx into the troposphere produces surface variations not related to surface emissions (Hamilton \& Fan, 2000; Hirsch et al., 2006; Montzka et al., 2018; C. D. Nevison et al., 2004; Ray et al., 2020; Ruiz et al., 2021). In this work we relate our modeled STE fluxes to variations at the surface and throughout the stratosphere, linking the fluxes of $\mathrm{N}_{2} \mathrm{O}$ to $\mathrm{O}_{3}$ through stratospheric measurements. Our goal is to develop a set of model metrics founded on observations that are related to the STE $\mathrm{O}_{3}$ flux and can be used with an ensemble of models to determine a better, constrained estimate for the flux, including seasonal, interannual, and hemispheric patterns. This approach is similar to efforts involving the ozone depletion recovery time (Strahan et al., 2011) and climate projections (Liang et al., 2020; Tokarska et al., 2020).

In a previous work (Ruiz et al., 2021), we showed that historical simulations with three chemistry transport models (CTMs) were able to match the interannual surface variations observed in $\mathrm{N}_{2} \mathrm{O}$. These were clearly driven by the stratospheric quasi-biennial oscillation (QBO) which appears to be the major interannual signal in stratospheric circulation and STE (Baldwin et al., 2001; Kinnersley \& Tung, 1999; M. A. Olsen et al., 2019). In this work, we calculate the monthly latitudinal STE fluxes of $\mathrm{O}_{3}, \mathrm{~N}_{2} \mathrm{O}$, and $\mathrm{CFCl}_{3}$ (F11) and establish a coherent picture relating fluxes to observed abundances. In section 2, we examine the annual and interannual cycles as well as geographic patterns of modeled STE flux. In section 3, we relate the surface variability of $\mathrm{N}_{2} \mathrm{O}$ to its STE flux. We find some evidence to support our model result that the STE flux of depleted- $\mathrm{N}_{2} \mathrm{O}$ air is greater in the southern hemisphere than in the northern, thus altering the asymmetry in surface emissions in the source inversions (Nevison et al., 2007; Thompson et al., 2014). In section 4, we examine the lowermost stratosphere to understand the large north-south asymmetry found in $\mathrm{O}_{3}$ STE versus $\mathrm{N}_{2} \mathrm{O}$ or F11 STE, and find a clear signal of the Antarctic ozone hole in STE. In section 5, we summarize the sequence of model metrics, primarily using $\mathrm{O}_{3}$ and $\mathrm{N}_{2} \mathrm{O}$, that that will usefully narrow the range in the tropospheric $\mathrm{O}_{3}$ budget terms like STE, for the multi-model intercomparison projects used in tropospheric chemistry and climate assessments.

\section{Annual and interannual cycles of modeled STE flux}

The modeled STE fluxes here are calculated with the UCI CTM driven by 3-hour forecast fields from the ECMWF Integrated Forecast System (IFS; Cy38r1 T159L60), as are the calculations in R2021. The CTM uses the IFS native 160x320 Gauss grid $\left(\sim 1.1^{\circ}\right)$ with 60 layers, about 35 in the troposphere. The stratospheric chemistry uses the linearized model Linoz $\mathrm{v} 3$ and includes $\mathrm{O}_{3}, \mathrm{~N}_{2} \mathrm{O}, \mathrm{NO}_{y}, \mathrm{CH}_{4}$, and F11 as transported trace gases (Hsu \& Prather, 2010; Prather et al., 2015; Ruiz et al., 2021). There is no tropospheric chemistry, but rather a boundary-layer e-fold to a specified abundance, or a surface boundary reset to an abundance. The STE flux is calculated using the e90 definition of tropospheric grid cells (Prather et al., 2011) and the change in tropospheric tracer mass from before to after each tracer transport step (Hsu et al., 2005; Hsu 
and Prather, 2009). This method is extremely robust for $\mathrm{O}_{3}$ and self-consistent with a CTM's tracer transport (Hsu \& Prather, 2014; Tang et al., 2013).

\subsection{Model STE and tracer methods}

R2021 modeled the surface signal of stratospheric loss with the decaying tracers, N2OX and F11X (e.g., Hamilton and Fan, 2000; Hirsch et al., 2006). These X-tracers have the identical stratospheric chemical loss frequencies as $\mathrm{N}_{2} \mathrm{O}$ and $\mathrm{CFCl}_{3}$, respectively, but no surface sources and are therefore affected only by the stratospheric sink and atmospheric transport. The multidecade (F11X) to century (N2OX) decays are easily rescaled on a month-by-month basis (using a 12-month smoothing filter) to give stationary results and a tropospheric mean abundance of $320 \mathrm{ppb}$. We treat F11X like N2OX with the same initial conditions and molecular weight (i.e., $\mathrm{Tg} \equiv \mathrm{TgN}$ with $2 \mathrm{~N}$ 's per molecule). These rescaled tracers we designate simply as $\mathrm{N} 2 \mathrm{O}$ and F11. Our F11-derived STE fluxes are thus unrealistically large compared to current $\mathrm{CFCl}_{3}$ fluxes, but they can be easily compared with our N2OX results.

Unfortunately, calculating the STE flux of N2OX and F11X using the Hsu method was numerically noisy because their gradients across the tropopause are minimal, unlike $\mathrm{O}_{3}$. We thus created complementary tracers $\mathrm{cN} 2 \mathrm{OX}$ and $\mathrm{cF} 11 \mathrm{X}$. For each $\mathrm{kg}$ of the $\mathrm{X}$-tracer (i.e., N2OX) destroyed by photochemistry, $1 \mathrm{~kg}$ of its complementary tracer $(\mathrm{cN} 2 \mathrm{OX})$ is created. Air parcels that are depleted in $\mathrm{N} 2 \mathrm{OX}(\mathrm{F} 11 \mathrm{X})$ are therefore rich in $\mathrm{cN} 2 \mathrm{OX}(\mathrm{cF} 11 \mathrm{X})$. After crossing the tropopause, $\mathrm{cN} 2 \mathrm{OX}$ and $\mathrm{cF} 11 \mathrm{X}$ are removed through rapid uptake in the boundary layer, thus creating sharp gradients at the tropopause. As a check, we compared the boundary layer sink of the c-tracers with their e90-derived STE flux and find that their sums are identical. The c-tracers and their STE fluxes are rescaled as their corresponding X-tracers to give them a stationary tropospheric abundance of $320 \mathrm{ppb}$, we designate these scaled tracers simply a cN2O and cF11. The inclusion of these new c-tracers provides the missing link in R2021 by directly connecting the stratospheric loss signals to STE flux and subsequent surface variability.

\subsection{Mean STE fluxes}

The STE fluxes calculated at every time step for each latitude-longitude grid column are integrated in time and longitude to give latitude-by-month resolved fluxes for years 1990-2017. Equivalent effective stratospheric chlorine levels are high enough to drive an Antarctic ozone hole, which is observed throughout this period. Thus, the ozone-hole chemistry in Linoz v3 is activated for all years, and the amount of $\mathrm{O}_{3}$ depleted depends on the Antarctic meteorology of that year. Annual-mean STE fluxes are calculated from the full 28-year (336 month) time series, and monthly-mean fluxes are calculated from the 28 values for each month.

The 28-year mean of global $\mathrm{O}_{3} \mathrm{STE}$ is $390 \pm 16 \mathrm{Tg} / \mathrm{yr}$ (positive flux means stratosphere to troposphere, the \pm values are the standard deviation of the 28 annual means), that of $\mathrm{cN} 2 \mathrm{O}$ is $11.5 \pm 0.7 \mathrm{Tg} / \mathrm{yr}$, and that of $\mathrm{cF} 11$ is $23.5 \pm 1.5 \mathrm{Tg} / \mathrm{yr}$. These fluxes for $\mathrm{cN} 2 \mathrm{O}$ and $\mathrm{cF} 11$ match the total long-term troposphere-to-stratosphere flux of $\mathrm{N} 2 \mathrm{O}$ and $\mathrm{F} 11$ as derived from their stratospheric losses. The $\mathrm{cF} 11$ budget is about twice as large as $\mathrm{cN} 2 \mathrm{O}$, because $\mathrm{F} 11$ is 
photolyzed rapidly in the lower-middle stratosphere $(\sim 24 \mathrm{~km})$ instead of the upper stratosphere like N2O. The seasonal mean pattern of STE fluxes are shown in Figure 1. The large majority of STE flux enters the troposphere at $25^{\circ}-45^{\circ}$ latitude in each hemisphere, but there is a broadening of the northern flux to $65^{\circ} \mathrm{N}$ in Jun-Jul. The importance of this region about the subtropical jet for STE is supported by satellite data where stratospheric folding events (high $\mathrm{O}_{3}$ in the upper troposphere) are found at the bends of the jet (Tang and Prather 2010, Atmos. Chem. Phys., 10, 9681-9688, 2010).

Given the small STE fluxes in the core tropics, the northern hemisphere $(\mathrm{NH})$ and southern hemisphere (SH) fluxes are distinct. The annual mean of $\mathrm{NH} \mathrm{O}_{3} \mathrm{STE}$ is $208 \pm 11 \mathrm{Tg} / \mathrm{yr}( \pm$ standard deviation over the 28 years) and is slightly larger than the SH mean of $182 \pm 11 \mathrm{Tg} / \mathrm{yr}$. This NH:SH ratio of 53:47 is typically found in other studies (Yang et al., 2016; Gettelman et al., 1997; Hsu and Prather, 2009). In contrast, for $\mathrm{cN} 2 \mathrm{O}$ and $\mathrm{cF} 11$, the $\mathrm{NH}$ flux $(5.1 \pm 0.4 \mathrm{Tg} / \mathrm{yr}$ and $10.6 \pm 0.8 \mathrm{Tg} / \mathrm{yr}$, respectively) is smaller than the SH flux $(6.4 \pm 0.5 \mathrm{Tg} / \mathrm{yr}$ and $12.9 \pm 1.0 \mathrm{Tg} / \mathrm{yr}$, respectively), giving a NH:SH ratio of about 45:55. The established view on STE is that the flux is wave-driven and under downward-sideways control, and thus the $\mathrm{NH}$ flux is much greater than the SH flux (see Table 1 of Holton et al., 1995; Appenzeller et al., 1996). Our unexpected results require further analysis including evidence for hemispheric asymmetry in observations which is shown in section 4 along with other model metrics.

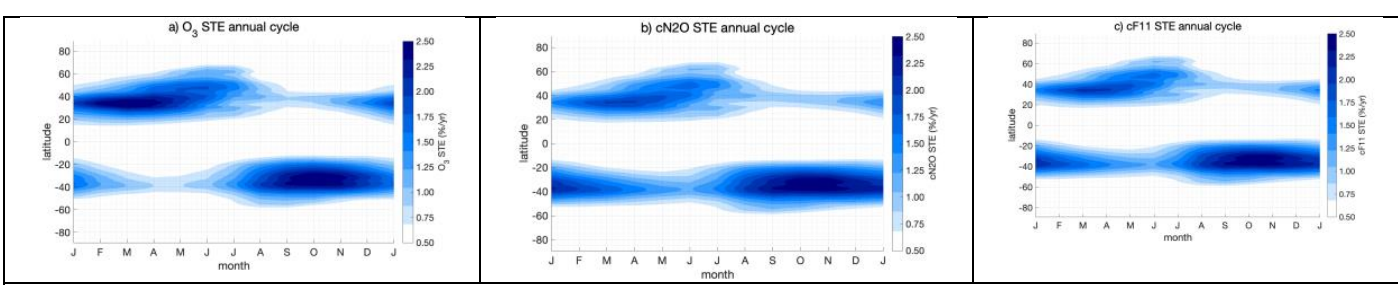

Figure 1. The seasonal (latitude by month) cycle of STE flux (Tg/yr) for (a) $\mathrm{O}_{3}$, (b) cN2O, and (c) cF11. Each month is averaged for years 1990-2017 (e.g., the 28 Januarys are averaged). The colorbar units are $\%$ of global, annual mean STE in each bin ( 1 month by $\sim 1.1^{\circ}$ latitude).

\subsection{Seasonal cycle of STE}

The seasonal cycles of STE fluxes summed over global, NH, and SH are shown in Figure 2. The scales are given as the annual rate (as if the monthly rate were maintained for the year), and each species has a different axis. The right y-axes are kept at a N2O:F11 ratio of 1:2. Despite large differences in the stratospheric chemistry across all three species, the seasonal cycle of STE is highly correlated $\left(>0.98\right.$, except for $\left.\mathrm{SH} \mathrm{O}_{3}\right)$, indicating that all three enter the troposphere from a seasonally near-uniform mixture of $\mathrm{O}_{3}: \mathrm{N} 2 \mathrm{O}: \mathrm{F} 11$ in the lowermost stratosphere.

Global STE peaks in June and reaches a minimum in November, but that merely reflects the dominance of the NH seasonal cycle and hides the distinct patterns in each hemisphere. The two hemispheres have dramatically different seasonal amplitudes and somewhat opposite phases. NH peak STE for all 3 species occurs in the late boreal spring (May-Jun), while that in the SH occurs at the start of austral spring (Sep-Oct). In the NH O 3 STE peaks a month before the ctracers, and in the SH the whole annual cycle is shifted a month earlier. The NH STE seasonal 
amplitude is very large for all species ( 4:1 peak-to-peak) with exchange almost ceasing in the fall. In contrast, the SH STE is more uniform year-round with seasonal amplitudes of 1.5:1 for $\mathrm{cN} 2 \mathrm{O}$ and $\mathrm{cF} 11$, and 2.2:1 for $\mathrm{O}_{3}$. Other models with similar $\mathrm{NH}$ and $\mathrm{SH} \mathrm{O}_{3}$ fluxes show different seasonal amplitudes and phasing (see Fig. 6 of Tang et al., 2021), which will affect tropospheric $\mathrm{O}_{3}$ abundances. It is important to develop observational metrics that test the seasonality of the lowermost stratosphere related to STE fluxes, and to establish monthly STE fluxes as a standard model diagnostic.

An interesting result here is the very tight correlation of the monthly cN2O and cF11 STE while the $\mathrm{O}_{3}$ STE is sometimes shifted. Loss of $\mathrm{N}_{2} \mathrm{O}$ and $\mathrm{F} 11$ occurs at very different altitudes in the tropical stratosphere ( $\sim 32 \mathrm{~km}$ and $\sim 24 \mathrm{~km}$, respectively), but both have similar seasonality in loss, driven mostly by the intensity of sunlight along the Earth's orbit $\left(\mathrm{N}_{2} \mathrm{O}\right.$ loss peaks in Feb and reaches a minimum in Jul, see Fig. 4 from Prather et al., 2015). Photochemical losses of $\mathrm{N}_{2} \mathrm{O}$ and F11 drop quickly for air descending from the altitudes of peak loss in the tropics and hence the relative $\mathrm{cN} 2 \mathrm{O}$ and $\mathrm{cF} 11$ STE fluxes are locked in. $\mathrm{O}_{3}$, however, continues to photochemically evolve from $24 \mathrm{~km}$ to $16 \mathrm{~km}$ (upper boundary of the lowermost stratosphere), through net photochemical loss that depends on sunlight and is thus seasonal. There may be observational evidence for the patterns modeled here in the correlation of these three tracers in the lower $(16-20 \mathrm{~km})$ and lowermost (12-16 km) extratropical stratosphere (see section 4).

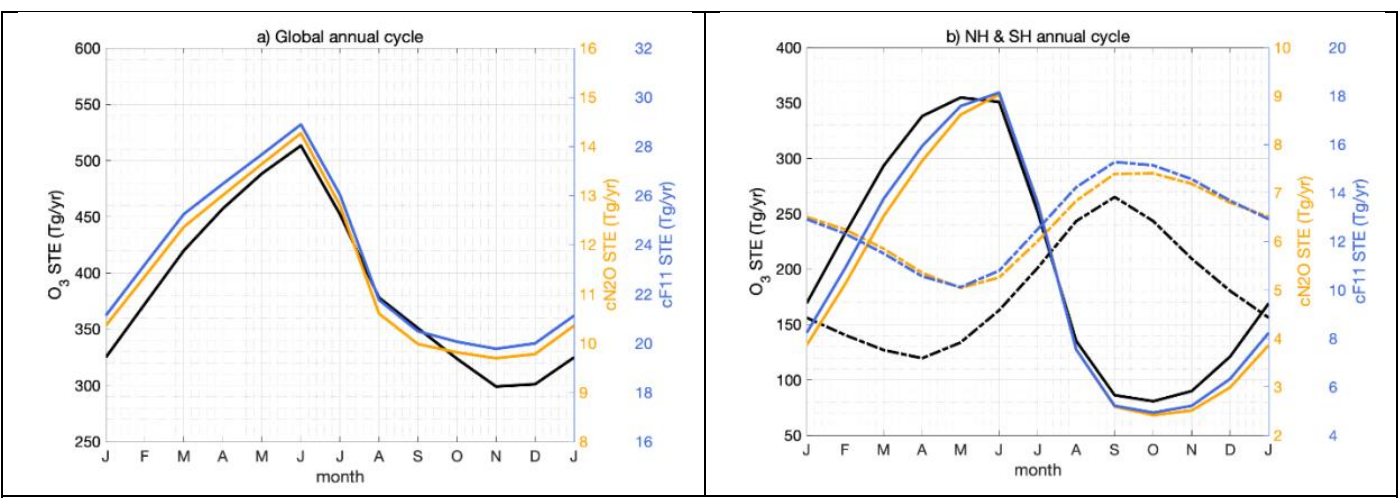

Figure 2. The annual cycle of monthly STE (Tg/yr) of $\mathrm{O}_{3}$ (black lines), cN2O (orange lines), and cF11 (blue lines). (a) Global STE fluxes, and (b) hemispheric STE fluxes (NH, solid lines; SH, dashed lines). Each month is averaged for years 1990-2017 (e.g., the 28 Januarys are averaged). Note the different y-axes for each tracer in each panel.

\subsection{Interannual variability of STE}

Interannual variability (IAV) of $\mathrm{N}_{2} \mathrm{O}$ loss and its lifetime is associated primarily with the QBO (most recently, R2021). When the QBO is in its easterly (westerly) phase the entire overturning circulation is enhanced (suppressed) (Baldwin et al., 2001). This results in more (less) air rich in $\mathrm{N}_{2} \mathrm{O}$ and $\mathrm{F} 11$ being transported from the troposphere to the lower or middle stratosphere, thereby increasing (decreasing) the $\mathrm{N}_{2} \mathrm{O}$ and F11 sinks (Prather et al., 2015; Strahan et al., 2015). From the tropical stratosphere, the overturning circulation transports air depleted in $\mathrm{N}_{2} \mathrm{O}$ and F11 into the lowermost extratropical stratosphere, where it enters the troposphere. R2021 showed that the 
observed surface variability of $\mathrm{N}_{2} \mathrm{O}$ from this circulation can be modeled and has a clear QBO signal, but one that is not strongly correlated with QBO signal in stratospheric loss. $\mathrm{NH}$, and SH. Values are 12-month running means, and so the first modeled point at 1990.5 is the sum of STE for Jan through Dec of 1990. In Figures 3bc, we show the seasonal amplitude with double-headed arrows on the left $\left(\mathrm{O}_{3}\right)$ and right $(\mathrm{cN} 2 \mathrm{O}$ and $\mathrm{cF} 11)$. In a surprising result, the large $\mathrm{NH}-\mathrm{SH}$ differences in seasonal amplitude are not reflected in the IAV where $\mathrm{NH}$ and $\mathrm{SH}$ amplitudes are similar for all three tracers. The QBO modulation of the lowermost stratosphere and STE appears to be unrelated to the seasonal cycle in STE.

Global STE for all three tracers is shows QBO-like cycling throughout the 1990-2017 time series: $\mathrm{cN} 2 \mathrm{O}$ and cF11 are well correlated $(\sim 0.9)$, but $\mathrm{O}_{3}$ is less so $(<0.7)$. The hemispheric breakdown provides key information regarding $\mathrm{O}_{3}$. In the NH the STE IAV is similar across all three tracers with high correlation coefficients $\left(0.82\right.$ for $\mathrm{O}_{3}-\mathrm{cN} 2 \mathrm{O}, 0.83$ for $\mathrm{O}_{3}-\mathrm{cF} 11$, and 0.94 for $\mathrm{cN} 2 \mathrm{O}-\mathrm{cF} 11)$. Conversely in the $\mathrm{SH}, \mathrm{O}_{3} \mathrm{STE}$ diverges from the c-tracer fluxes, showing opposite-sign peaks in 2003 and 2016. The corresponding SH correlations are $(0.38,0.65 .0 .85)$. The loss of correlation between $\mathrm{cN} 2 \mathrm{O}$ and $\mathrm{cF} 11$ is unusual: $\mathrm{cN} 2 \mathrm{O}$ drifts downward relative to cF11, particularly after 2007; nevertheless, the fine structure after 2007 is well matched in both tracers.

In the $\mathrm{SH}$, the massive loss of $\mathrm{O}_{3}$ within the Antarctic vortex, when mixed with the extra-polar lowermost stratosphere will systematically shift the $\mathrm{O}_{3}$ STE to lower values, with lesser impact on the $\mathrm{cN} 2 \mathrm{O}$ and $\mathrm{cF} 11$ STE. The IAV of the Antarctic winter vortex in terms of the amount of $\mathrm{O}_{3}$ that is deplete (World Meteorlogical Organization (WMO), 2018, figure 4-4) appears to drive the decorrelation of the SH STE fluxes and is analyzed in section 4.

In the $\mathrm{NH}$, the high variability of the Arctic winter stratosphere can modulate the total $\mathrm{O}_{3} \mathrm{STE}$ flux (e.g., (Hsu \& Prather, 2009) but appears to maintain the same relative ratio with the $\mathrm{cN} 2 \mathrm{O}$ and cF11 fluxes. The model results here indicate that there is no differential IAV chemical signal in these $\mathrm{NH}$, and that the lowermost stratosphere is still combining the same chemical mixtures of air masses from year to year. We know there is a large IAV in the Arctic winter activation of halogen-driven $\mathrm{O}_{3}$ depletion (Manney et al., 2020), but the magnitude is still much smaller than in the Antarctic, and it may not reach into the lowermost stratosphere $(<380 \mathrm{~K}$ potential temperature). This model accurately simulates Antarctic $\mathrm{O}_{3}$ loss (section 4), but we have not evaluated it for Arctic loss, and the Arctic conditions operate closer to the thresholds initiating loss where Linoz v3 chemistry may be inadequate. The same meteorology and transport model with full stratospheric chemistry is able to simulate Arctic $\mathrm{O}_{3}$ loss (Oslo's CTM2: Isaksen et al., 2012), and thus it will be possible to re-evaluate the NH IAV with such models or with lowermost stratosphere tracer measurements. 


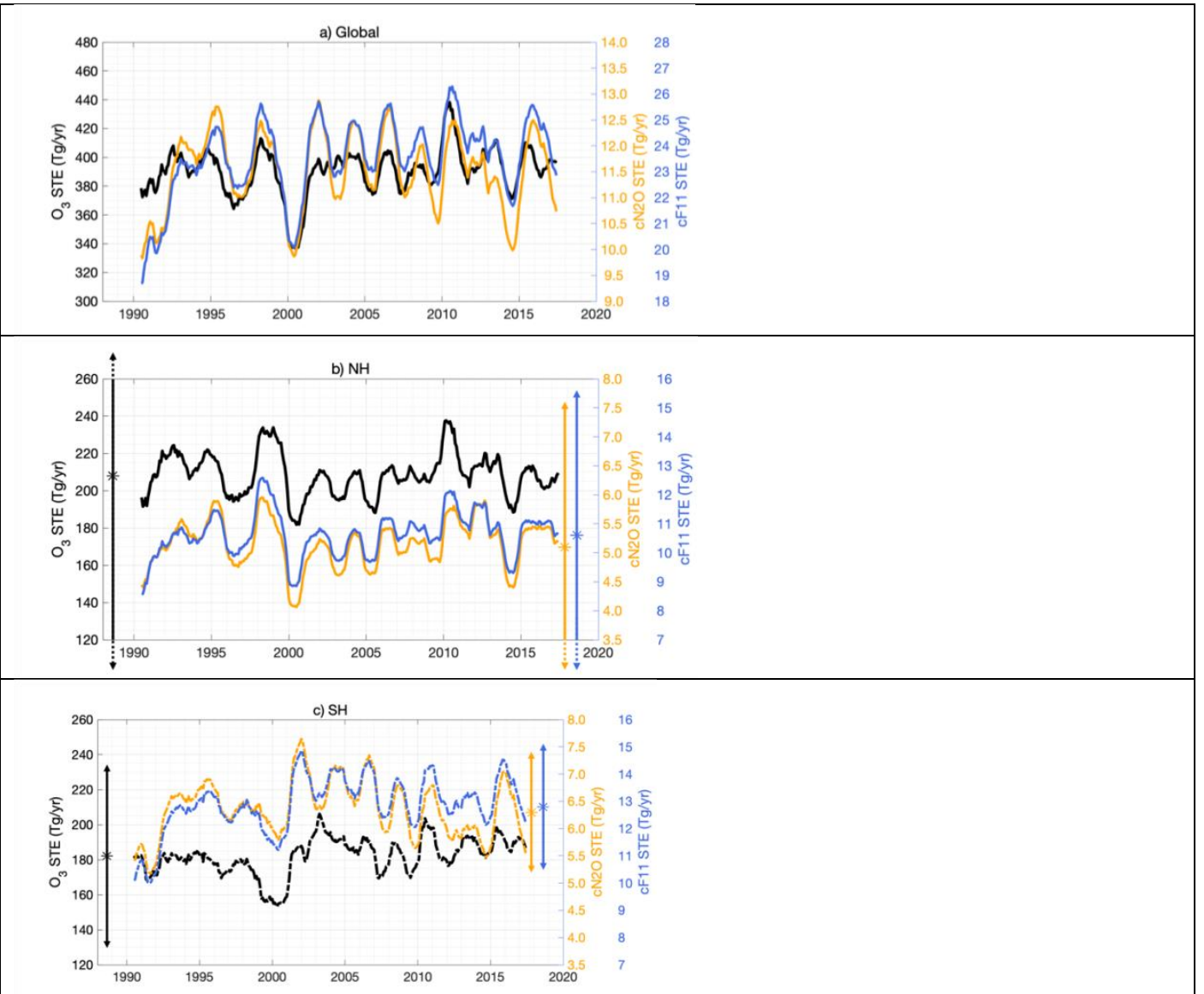

Figure 3. (a) Global STE (Tg/yr), calculated at e90 tropopause, of $\mathrm{O}_{3}$ (black line; left y-axis), cN2O (orange line; orange right y-axis), and cF11 (blue line; blue right y-axis) for years 1990-2017. Values are 12-month running means, and so the first point at 1990.5 is the sum of STE for Jan through Dec of 1990. (b) NH STE. (c) SH STE. The scales for $\mathrm{cN} 2 \mathrm{O}$ and $\mathrm{cF} 11$ are kept in a 1:2 ratio. The asterisks and vertical double-headed arrows (b \& c) depict the seasonal mean and amplitude for each species in each hemisphere.

\subsection{From stratospheric loss to STE}

What is unusual about the very tight correlation of $\mathrm{cN} 2 \mathrm{O}$ and $\mathrm{cF} 11$ STE fluxes is that the photochemical loss of $\mathrm{N} 2 \mathrm{O}$ and $\mathrm{F} 11$ occurs at very different altitudes in the tropical stratosphere, which are not in phase with respect to the QBO as shown in R2021 (their Fig. 2). The separate phasing of $\mathrm{cN} 2 \mathrm{O}$ and $\mathrm{cF} 11$ production is lost, presumably by diffusive tracer transport, by the time they reach the extratropical lowermost stratosphere. The overall synchronization of the STE fluxes implies that the absolute STE flux is driven primarily by variations in venting of the lowermost stratosphere as expected (Appenzeller et al., 1996; Holton et al., 1995) rather than by variations in the chemistry of the middle stratosphere. 
This disconnect between the chemical signals generated by the prominent QBO signature of wind reversals and upwelling in the tropical stratosphere and the STE fluxes is also clear in the magnitude of the loss versus STE. For $\mathrm{N}_{2} \mathrm{O}$, the IAV of $\mathrm{cN} 2 \mathrm{O}$ production has a range of \pm 0.5 $\mathrm{Tg} / \mathrm{yr}$, whether from Microwave Limb Sounder (MLS) observations or the model; whereas the IAV of cN2O STE flux is $\pm 1.1 \mathrm{Tg} / \mathrm{yr}$. The same is true in relative terms for $\mathrm{cF} 11$. Thus, the modulation of the lowermost stratosphere by the QBO, which is clearly a part of the overall changes in stratospheric circulation related to the QBO (Tung \& Yang, 1994; Kinnersley and Tung, 1999), is the dominant source of IAV for these three greenhouse gases.

\subsection{The QBO signal of STE}

To examine the QBO cycle in STE flux, we build a composite pattern (see R2021, Fig. 3 of $\mathrm{N}_{2} \mathrm{O}$ surface variations), by synchronizing the STE IAV in Figure 2 with the QBO cycle. The sync point (offset $=0$ months) is taken from one of the standard definitions of the QBO phase change, i.e., the shift in sign of the 40-hPa tropical zonal wind from easterly to westerly (Newman, 2020). The 1990-2017 model period has 12 QBO cycles, but we restrict our analysis here to years 2001-2016 to overlap with the observed surface $\mathrm{N}_{2} \mathrm{O}$ data. This period includes seven QBO phase transitions (01/2002, 03/2004, 04/2006, 04/2008, 08/2010, 04/2013, 07/2015), but the QBO centered on 08/2010 is highly anomalous (Coy et al., 2017; P. Newman et al., 2016; Osprey et al., 2016), and we remove it from our comparison. The resulting QBO composites for NH and SH in Figure 4 span 28 months.

In the NH, the QBO modulation of all three tracers is similar: STE flux begins to increase at an offset of -8 months and continues to increase slowly for a year, peaking at offset $=+4$; thereafter it decreases more rapidly in about $1 / 2$ year (offset $=+10$ ). The rise-and-fall cycle takes about 18 months. In the $\mathrm{SH}$, the pattern for $\mathrm{cN} 2 \mathrm{O}$ and $\mathrm{cF} 11$ is more sinusoidal and is shifted later by $\sim 3$ months. The SH amplitude of the c-tracers is slightly larger relative to the hemispheric mean flux than in the NH, and thus the SH QBO signal is larger than the NH by about $40 \%$. Thus, over the QBO cycle centered on the sync point, more depleted $\mathrm{N}_{2} \mathrm{O}$ and $\mathrm{F} 11$ is entering the $\mathrm{SH}$ than in the NH. For $\mathrm{O}_{3}$, the $\mathrm{SH}$ modulation of STE is irregular and reduced compared with the $\mathrm{NH}$. Our hypothesis here, consistent with the annual cycle of STE (Figure 1), is that the breakup of the Antarctic ozone hole has a major impact on STE, particularly that of $\mathrm{O}_{3}$, and that its signal has large IAV that does not synchronize with the other source of IAV, the QBO. Surprisingly, the large wintertime IAV in the NH Arctic, in the form of sudden stratospheric warmings, does not seem to have a major role in STE fluxes as noted above. This model may miss some of the Arctic $\mathrm{O}_{3}$ depletion, but it accurately simulates the warmings, which must have a small impact on STE because they do not disrupt the clear QBO signal in the c-tracers. 


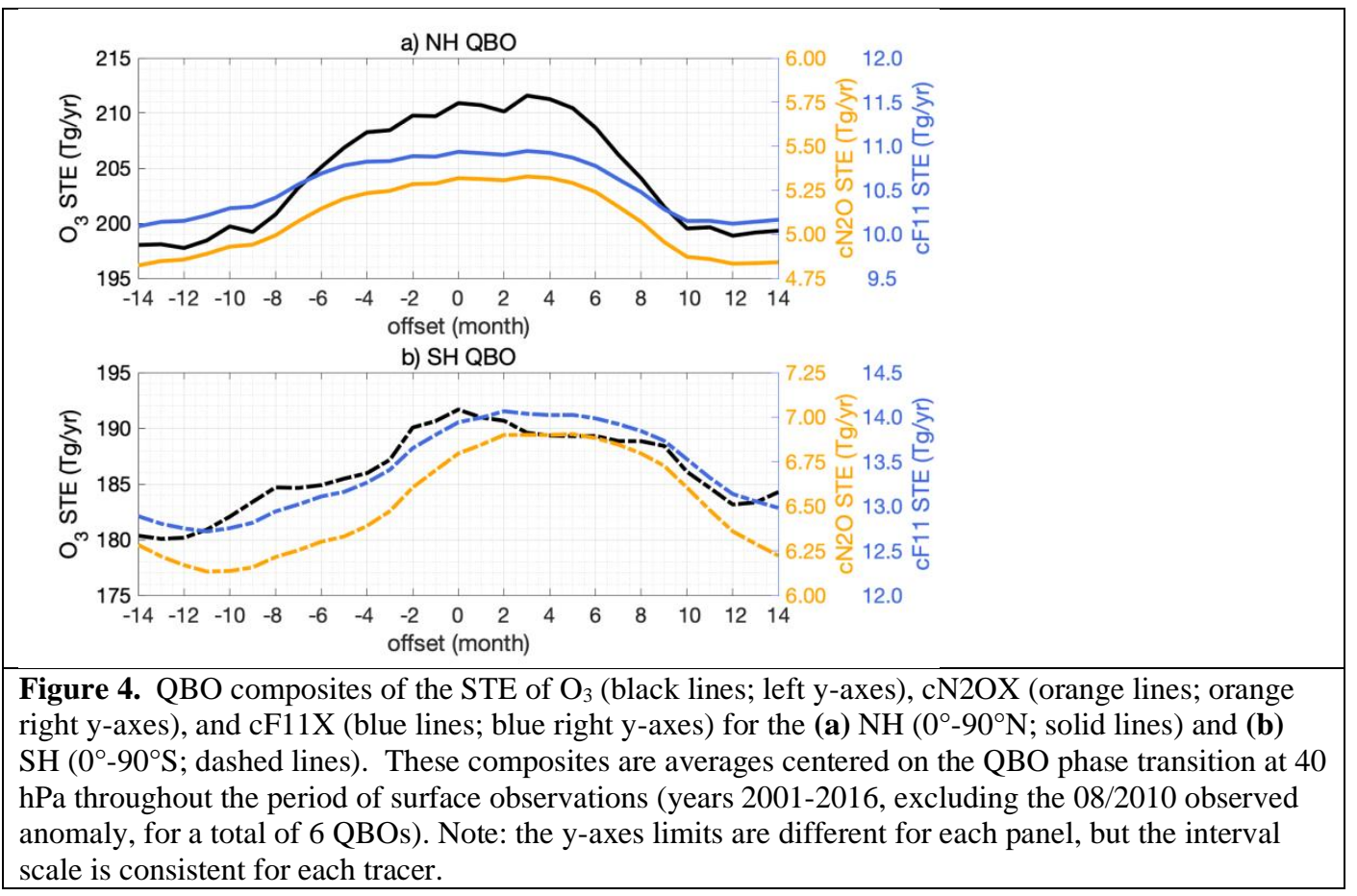

\section{Surface variability of $\mathrm{N}_{2} \mathrm{O}$ related to STE flux}

Surface variability of $\mathrm{N}_{2} \mathrm{O}$ is driven by surface emissions, stratospheric loss, and atmospheric transport that mixes the first two signals. R2021 explored the variability originating only from stratospheric chemistry using the decaying tracer N2OX and we use surf- $\mathrm{N} 2 \mathrm{O}$ to denote the surface abundances of N2OX when corrected to steady state. R2021 showed that three independent chemistry-transport models produced annual and QBO patterns in surface $\mathrm{N}_{2} \mathrm{O}$ simply from stratospheric loss. In this paper we link surf-N2O to the STE cN2O flux, which is linked above to the $\mathrm{STE} \mathrm{O}_{3}$ flux.

The observed surface $\mathrm{N}_{2} \mathrm{O}$ (denoted obs- $\mathrm{N}_{2} \mathrm{O}$ and taken from the NOAA network (Dlugokencky et al, 2019)) shows a slowly increasing abundance ( $0.9 \mathrm{ppb} / \mathrm{yr})$ with a clear signal of annual and interannual variability at some latitudes (see R2021). We calculate annual and QBO-composite obs- $\mathrm{N}_{2} \mathrm{O}$ after de-trending and restrict analysis in this section to model years 2001-2016 to be consistent with the surface data. The latitude-by-month pattern of obs- $\mathrm{N}_{2} \mathrm{O}$ includes the impact of both stratospheric loss $(\sim 13.5 \mathrm{Tg} / \mathrm{yr})$ and surface emissions $(\sim 17 \mathrm{TgN} / \mathrm{yr})$, with the preponderance of emissions being in the NH (Tian et al., 2020). Total emissions are not expected to have large IAV but may have a seasonal cycle. The seasonal variation of surface $\mathrm{N}_{2} \mathrm{O}$ can also be driven by seasonality in the interhemispheric mixing of the $\mathrm{NH}-\mathrm{SH}$ gradient $(\sim 1$ $\mathrm{ppb})$. 


\subsection{Annual cycle}

Figure 5 replots the hemispheric mean annual cycles of cN2O STE flux alongside the annual cycles of surf- $22 \mathrm{O}$ and obs- $\mathrm{N}_{2} \mathrm{O}$. As noted above, the STE in each hemisphere is almost in opposite phase, as is the modeled surf-N2O (taken from Fig. 5 of R2021). The NH:SH amplitude ratio is about 2.4:1 for both STE and surf-N2O. The lag from peak STE flux of cN2O (negative $\mathrm{N}_{2} \mathrm{O}$ ) to minimum surf- $2 \mathrm{O}$ is about 3 months. Such a $90^{\circ}$ phase shift is expected for the seasonal variation of a long-lived tracer relative to a seasonal source or sink. The time lag between the signal at the tropopause and at the surface, the tropospheric turnover time, should be no more than a month. Surprisingly, the $\mathrm{cN} 2 \mathrm{O}$ STE seasonal amplitude is much larger in the NH $( \pm 3.4 \mathrm{Tg} / \mathrm{y})$ than in the $\mathrm{SH}( \pm 1.3 \mathrm{Tg} / \mathrm{y})$, although the $\mathrm{SH}$ mean $(6.5 \mathrm{Tg} / \mathrm{y})$ is larger than the $\mathrm{NH}$ $(5.2 \mathrm{Tg} / \mathrm{yr})$. Essentially, there is more variability of air depleted in $\mathrm{N}_{2} \mathrm{O}$ entering the $\mathrm{NH}$, but air entering the SH has a larger overall deficit. Thus in our model, the stratosphere creates a NH-SH gradient of $+0.3 \mathrm{ppb}$ at the surface, which is a significant fraction of the observed N-S difference of $+1.3 \mathrm{ppb}$ (R2021). This important result needs to be verified with other models or analyses because it constrains the NH-SH location of sources.

In the $\mathrm{NH}$, as noted in $\mathrm{R} 2021$, the two surface abundances, surf- $\mathrm{N} 2 \mathrm{O}$ and obs- $\mathrm{N}_{2} \mathrm{O}$, have the same amplitude and phase, implying that, if the model is correct, the emissions-driven surface signal has no seasonality. In the $\mathrm{SH}$, the surf-N2O signal is much smaller in parallel with the small seasonal amplitude in cN2O STE, but it is out of phase with the obs- $\mathrm{N}_{2} \mathrm{O}$. This result implies that the SH has some highly seasonal sources, or simply that the forcing of SH surf-N2O by the seasonal cycle of $\mathrm{cN} 2 \mathrm{O}$ is weak. Indeed, this is what we might expect from Figure 3: In the $\mathrm{NH}$ the seasonal amplitude in $\mathrm{N}_{2} \mathrm{O}$ overwhelms the IAV amplitude and is driving the obs$\mathrm{N}_{2} \mathrm{O}$; but in the $\mathrm{SH}$, both amplitudes are comparable. Given the quasi nature of the QBO, it would interfere with the seasonal cycle and likely change its phase (as found for other models in R2021).

In the $\mathrm{NH}$, the annual cycle of $\mathrm{O}_{3}$ and $\mathrm{cN} 2 \mathrm{O}$ STE are clearly linked. If we accept that the obs$\mathrm{N}_{2} \mathrm{O}$ NH seasonal cycle is simply driven by the STE flux, then how will tropospheric $\mathrm{O}_{3}$ respond seasonally? A mole-fraction scaling of the STE fluxes gives an $\mathrm{O}_{3}: \mathrm{N}_{2} \mathrm{O}$ ratio of $\sim 25$, and thus scaling the surf- $2 \mathrm{O}$ amplitude gives a large $\mathrm{O}_{3}$ surface seasonality of $\sim 18 \mathrm{ppb}$. However, the residence time of a tropospheric $\mathrm{O}_{3}$ perturbation is $\sim 1$ month, and thus the peak surface abundance will lag the peak STE flux by only about a month and not by 3 months as for $\mathrm{N}_{2} \mathrm{O}$. $\mathrm{O}_{3}$ will equilibrate with the flux on monthly timescales and not accumulate. Thus, our estimate is that $\mathrm{NH} 30^{\circ}-90^{\circ}$ surface ozone might increase about $5 \mathrm{ppb}$, peaking in June, due to the STE flux. In the $\mathrm{SH}$, seasonal patterns are weaker and not well defined, and thus no obvious $\mathrm{STE} \mathrm{O}_{3}$ signal is expected. 


\section{2. $Q B O$ cycle}

The QBO composite of hemispheric mean cN2O STE flux from Figure 4 is compared with the composite of surface abundances (surf-N2O and obs- $\mathrm{N}_{2} \mathrm{O}$ ) in Figure 6. The peak in $\mathrm{cN} 2 \mathrm{O}$ flux is broad and flat, but centers on +2 months for the $\mathrm{NH}$ and +4 months for the $\mathrm{SH}$. Unlike the annual cycle, the QBO cycle in STE flux is almost in phase in both hemispheres, with the NH preceding the $\mathrm{SH}$. This phasing of the $\mathrm{QBO}$ cycle in surface $\mathrm{N}_{2} \mathrm{O}$ was seen with the three models in R2021. In both hemispheres, the modeled surf-N2O peaks before the rise in cN2O and then decreases through most of the period with elevated $\mathrm{cN} 2 \mathrm{O}$ flux as expected. The amplitude of the QBO STE flux is smaller in the NH than SH by about half, and the amplitude of surf-N2O is likewise smaller. The ratio the amplitudes of surf-N2O to cN2O STE flux is similar in both hemispheres $(\sim 0.4 \mathrm{ppb}$ per $\mathrm{Tg} / \mathrm{yr})$, which is encouraging. This ratio is larger than the corresponding one from the annual cycles $(\sim 0.1 \mathrm{ppb}$ per $\mathrm{Tg} / \mathrm{yr})$ because the length of the QBO cycle leads to longer accumulation of $\mathrm{N}_{2} \mathrm{O}$-depleted air from the $\mathrm{cN} 2 \mathrm{O}$ flux. matches obs- $\mathrm{N}_{2} \mathrm{O}$ in amplitude and phase as reported in $\mathrm{R} 2021$. In the $\mathrm{NH}$, the comparison of surf- $2 \mathrm{O}$ with obs- $\mathrm{N}_{2} \mathrm{O}$ is not so good: obs-N2O has a much smaller amplitude and a different phase. This QBO cycle pattern is similar, but reversed, to that of the annual cycle and can be understood in the same way. The NH QBO cycle has relatively small amplitude and thus the 
interference with the large-amplitude annual cycle adds noise, obscuring the QBO cycle. In the $\mathrm{SH}$ it is the opposite, with its weak annual cycle, the SH QBO cycle is clear. The modeled cN2O fluxes enable us to understand the large-scale variability of the observations.

Thus, for both annual and QBO fluctuations, when the variation in STE flux is dominated by either cycle, the surface variations are clearly seen and modeled for that cycle. This further supports the findings in R2021 and other studies, that hemispheric surface $\mathrm{N}_{2} \mathrm{O}$ variability is driven by stratospheric loss on annual $(\mathrm{NH})$ and QBO $(\mathrm{SH})$ cycles, and it is clearly tied to the STE flux. Given the connection between $\mathrm{O}_{3}$ and $\mathrm{cN} 2 \mathrm{O}$ STE, this relational metric can be used to constrain the $\mathrm{O}_{3}$ STE for a model ensemble.

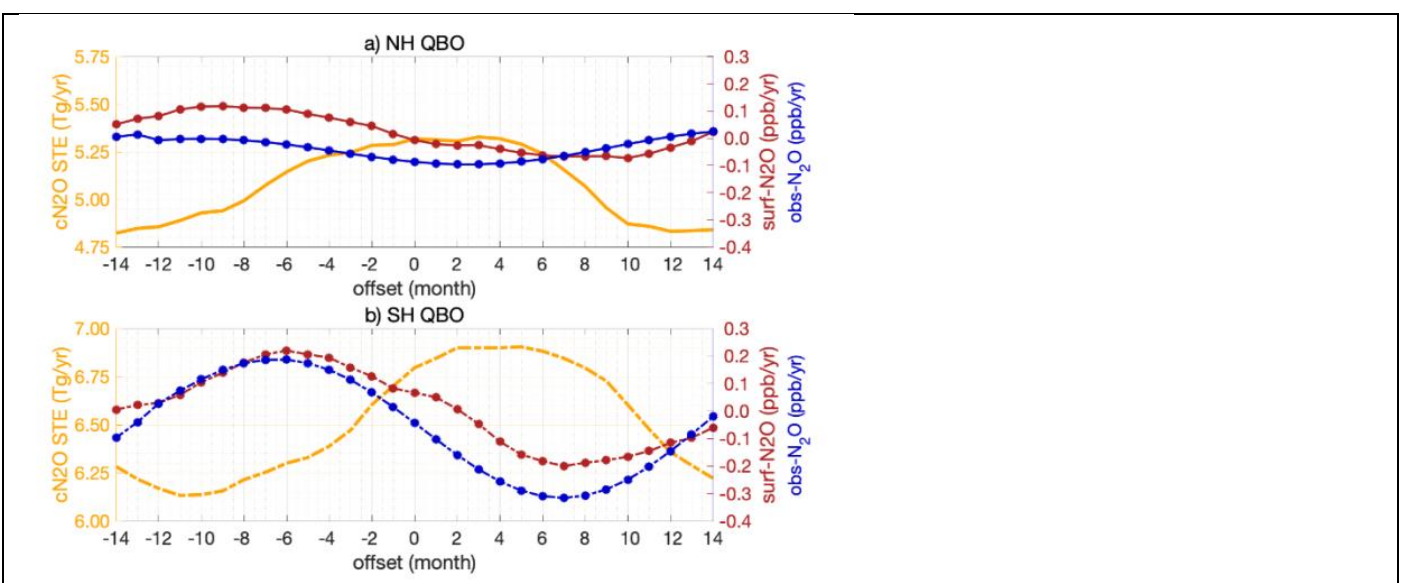

Figure 6. (a) NH and (b) SH QBO composites of cN2O STE flux (Tg/yr; orange lines, left axis, Fig. 4), and surf- $\mathrm{N} 2 \mathrm{O}$ and obs- $\mathrm{N}_{2} \mathrm{O}$ (ppb; red and blue knotted lines, right axes, see Fig. 3 of R2021). Results are shown for years 2001-2016 (6 QBO phase transitions), see Fig. 4. The surf-N2O data is from UCI CTM, and obs- $\mathrm{N}_{2} \mathrm{O}$ are taken from NOAA ESRL, see text.

\section{Lowermost stratosphere}

\subsection{The $\mathrm{O}_{3}: \mathrm{N}_{2} \mathrm{O}$ slopes and $\mathrm{STE}$ fluxes}

If we accept that matching the observed annual and QBO cycles in surface $\mathrm{N}_{2} \mathrm{O}$ constrains the modeled STE cN2O flux, then how can we use that to also constrain the modeled $\mathrm{STE} \mathrm{O}_{3}$ flux? All evidence, theoretical, observational, and modeled, shows that the STE flux is simultaneous for all species (e.g., Figure S1) and in proportion to their relative abundances in the lowermost stratosphere (Plumb \& Ko, 1992). We can test this hypothesis in our model framework by comparing the relative STE fluxes for $\mathrm{O}_{3}, \mathrm{cN} 2 \mathrm{O}$ and $\mathrm{cF} 11$ with the modeled tracer-tracer slopes in the lowermost stratosphere. These slopes can then be tested using SCISAT-1 ACE-FTS (Scientific Satellite-1 Atmospheric Chemistry Experiment-Fourier Transform Spectrometer) measurements of $\mathrm{O}_{3}$ and $\mathrm{N}_{2} \mathrm{O}$ in the lowermost stratosphere to establish the ratio of the two STE fluxes.

Figure $7 \mathrm{ab}$ shows the $\mathrm{N}_{2} \mathrm{O}-\mathrm{O}_{3}$ slope in each hemisphere taken from the ACE climatology dataset and the UCI CTM. The current ACE dataset (version 3.5) has been curated from measurements 
made by ACE-FTS from February 2004 to February 2013 (Koo et al., 2017). The SCISAT orbit results in irregular season-latitude coverage, and thus we average the lowermost stratosphere data over a wide range of latitudes centered on the peak STE flux $\left(20^{\circ}-60^{\circ}\right.$ in both hemispheres). For both ACE data and the CTM we keep to the lowermost stratosphere (200-100 hPa) and average over the 4-month peak of STE flux, Feb-May in the NH and Sep-Dec in the SH (see Figure +1)

Based on the long-term mean STE fluxes in the model, we would expect an $\mathrm{O}_{3}: \mathrm{N}_{2} \mathrm{O}$ slope of about $-24(\mathrm{ppb} / \mathrm{ppb})$ in the $\mathrm{NH}$ and -17 in the $\mathrm{SH}$. The slopes fitted to our modeled grid-cell values of $\mathrm{O}_{3}$ and $\mathrm{N}_{2} \mathrm{O}$ in the lowermost stratosphere are similar but smaller: -21.2 $(\mathrm{NH})$ and $15.5(\mathrm{SH})$. The ACE data are more scattered but show similar slopes of $-19.4(\mathrm{NH})$ and -15.3 (SH). Thus, the NH-SH asymmetry in $\mathrm{O}_{3}$ versus $\mathrm{N}_{2} \mathrm{O}$ STE fluxes is clearly reflected in the tracer-tracer slopes, both modeled and observed.

In the modeled SH (Figure 7b), one can see strings of points that are samples along neighboring cells and reflect a linear mixing line between two different end points, one of which has experienced extensive $\mathrm{O}_{3}$ depletion (i.e., the Antarctic $\mathrm{O}_{3}$ hole). We know that there is some chemical loss of $\mathrm{O}_{3}$ in the $\mathrm{NH}$ lowermost polar stratosphere during very cold winters (Isaksen et al., 2012; Manney et al., 2011), but it is not extensive enough to systematically affect the $\mathrm{O}_{3}: \mathrm{N}_{2} \mathrm{O}$ slope over the mid-latitude lowermost stratosphere in either the ACE observations or the CTM simulations.
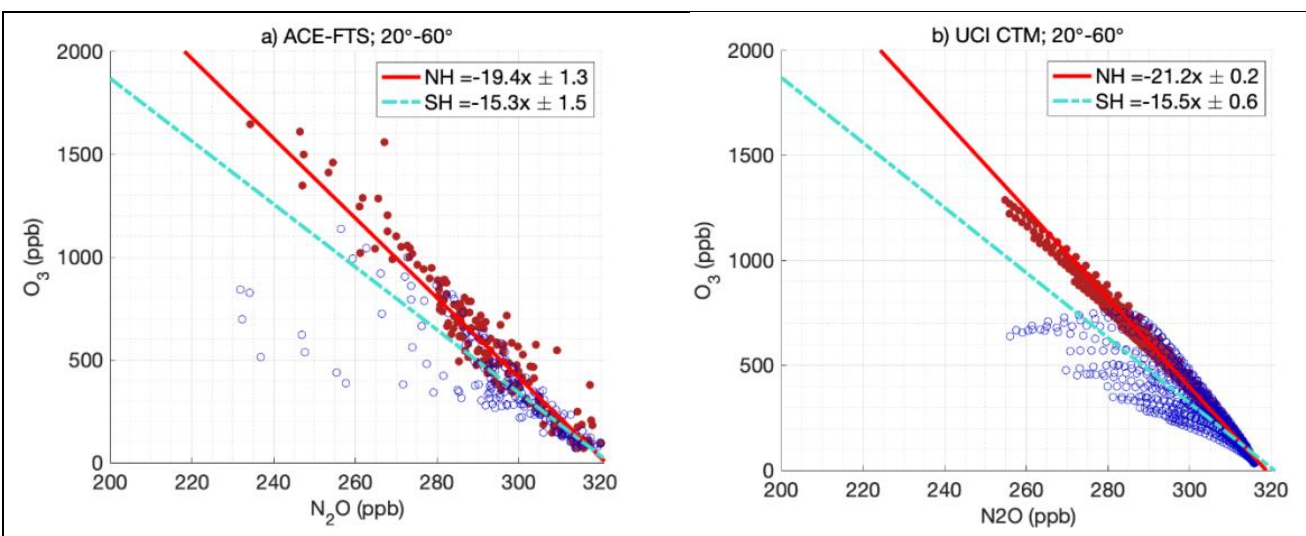

Figure 7. $\mathrm{O}_{3}$ versus $\mathrm{N}_{2} \mathrm{O}$ (x-axis) scatter plots from (a) SCISAT ACE-FTS and (b) the UCI CTM. ACE-FTS data is from monthly climatologies for the period Feb 2004 to Feb 2013 restricted to 200$100 \mathrm{hPa}$, latitudes about $20^{\circ}-60^{\circ}$, and months Feb-May (NH, red) or Sep-Dec (SH, blue). The linear-fit lines ( $\mathrm{ppb} / \mathrm{ppb}$, values in legend) are restricted to larger $\mathrm{N}_{2} \mathrm{O}$ values ( $>280 \mathrm{ppb}$ ) to more accurately represent the STE fluxes, see Olsen et al. (2001).

\subsection{IAV of the Antarctic ozone hole and the SH STE $\mathrm{O}_{3}$ flux}

The Antarctic ozone hole appears to be the source of the NH-SH asymmetry in the STE fluxes of $\mathrm{O}_{3}$ versus $\mathrm{N}_{2} \mathrm{O}$. The chemical depletion of $\mathrm{O}_{3}$ inside the vortex creates an air mass with lower 
$\mathrm{O}_{3}: \mathrm{N}_{2} \mathrm{O}$ ratios than found in the mid-latitude lowermost stratosphere. When the vortex breaks up, nominally in late November, this $\mathrm{O}_{3}$-depleted air mixes with the rest of the lowermost stratosphere and reduces the $\mathrm{SH} \mathrm{STE} \mathrm{O}_{3}$ flux.

We have additional information on the $\mathrm{SH} \mathrm{O}_{3} \mathrm{STE}$ flux from the year-to-year variations in the size of the ozone hole. The best measure of the scale of Antarctic ozone depletion is the October mean ozone column (DU) averaged from the pole to $63^{\circ} \mathrm{S}$ equivalent latitude (see Figure 4-5 of WMO (2018)). When we compare the CTM with the observations (Figure 8), we find remarkable verisimilitude in the model: the rms difference is 9 DU out of a standard deviation of $29 \mathrm{DU}$ and the correlation coefficient is 0.96. Thus, we have confidence that we are simulating the correct IAV of the ozone hole. Next, we plot the modeled $\mathrm{O}_{3}$ STE flux (summed over the 12 months following the peak ozone hole, Nov-Oct) and find a fairly linear relationship. If we estimate the $\mathrm{STE} \mathrm{O}_{3}$ flux before the $\mathrm{O}_{3}$ hole, when the mean October $\mathrm{O}_{3}$ column was about 307 DU, then our $\mathrm{O}_{3}$ flux is $209 \mathrm{Tg} / \mathrm{yr}$ (see Figure 7, red marker), eliminating the hemispheric asymmetry in $\mathrm{O}_{3}$ STE flux.

We looked for any relationship between ozone hole IAV and the STE fluxes of cN2O or cF11 and found mostly a scatter plot with no clear relationship. Given the analysis above, we expect that much of the scatter is related to QBO cycles.

463

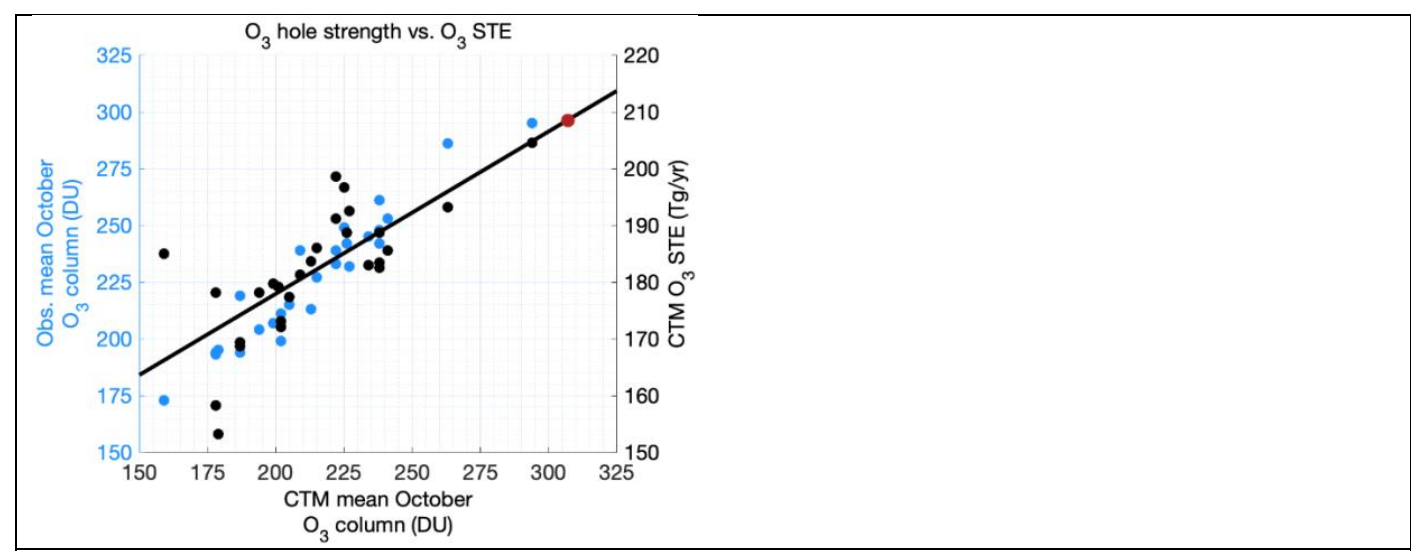

Figure 8. Interannual variability of the observed Antarctic ozone hole from 1990 to 2017 (blue dots; left y-axis) versus the CTM modeled ozone hole (x-axis); plus the CTM modeled SH STE $\mathrm{O}_{3}$ flux (black dots; right $\mathrm{y}$-axis) versus the modeled ozone hole (x-axis). The ozone hole is measured by the total ozone column (DU) averaged daily over October poleward of $63^{\circ} \mathrm{S}$ in equivalent latitude (see Figure 4.5 of WMO 2018). The SH STE $\mathrm{O}_{3}$ flux (Tg/yr) is centered on May 1 of the following year (i.e., the 12 months following the nominal breakup of the ozone hole). The black line is a simple regression fit of the modeled STE to the modeled ozone hole (black dots), and the red dot is our estimate of pre-ozone-hole $\mathrm{SH} \mathrm{STE} \mathrm{O}_{3}$ flux based on the observed 1979-82 $\mathrm{O}_{3}$ column. 
What else might affect $\mathrm{O}_{3}$ STE? Stratospheric column $\mathrm{O}_{3}$ (DU) varies on annual and QBO timescales (Tang et al., 2021). These changes in $\mathrm{O}_{3}$ overhead can have a direct influence on $\mathrm{O}_{3}$ transport to the troposphere, but the link requires further analysis. Tang et al. (2021) showed the UCI CTM is able to capture the observed annual cycle of stratospheric $\mathrm{O}_{3}$ column (extracted from total column using Ziemke method; Ziemke et al., 2019). QBO modulation of stratospheric column $\mathrm{O}_{3}$ has not been fully investigated but its magnitude, like that of the annual cycle, is comparable to the magnitude of $\mathrm{O}_{3}$ STE and is clearly somehow connected (Figure 9).
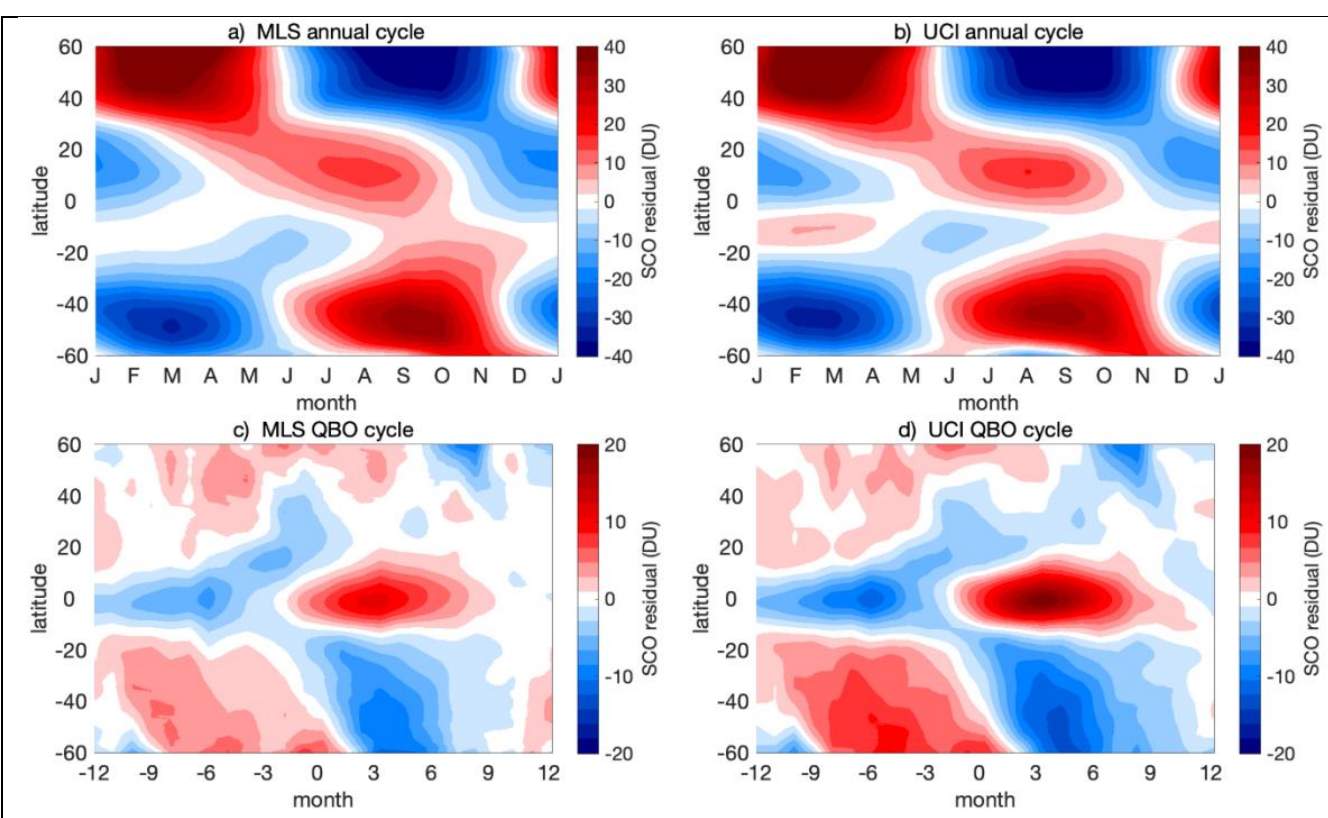

Figure 9. Stratospheric $\mathrm{O}_{3}$ column residuals taken from MLS (a, c) and UCI CTM (b, d) for their mean annual cycle (a, b) and mean QBO cycle (c, d) during years 2005-2017. Residuals are defined at each latitude with a mean of zero DU.

\section{Conclusions}

This work examines how closely $\mathrm{O}_{3}$ STE is linked to STE fluxes of other trace gases. By including our complementary $\mathrm{N}_{2} \mathrm{O}$ and $\mathrm{F} 11$ tracers, we can follow stratospheric loss of these gases along with stratospheric $\mathrm{O}_{3}$ across the tropopause. The magnitudes of the fluxes are proportional to their abundances in the lower stratosphere as expected (Plumb \& Ko, 1992), and their variability is highly correlated with one another, indicating that they are entering the troposphere simultaneously. Even during QBOs, which have their own distinct pattern of STE fluxes, we find that the link between $\mathrm{O}_{3}, \mathrm{~N}_{2} \mathrm{O}$ and F11 STE, remains consistent. We further constrain the $\mathrm{N}_{2} \mathrm{O}$ transport pathway by linking STE of depleted- $\mathrm{N}_{2} \mathrm{O}$ air with surface fluctuations of $\mathrm{N}_{2} \mathrm{O}$ abundance. The surface response in modeled $\mathrm{N}_{2} \mathrm{O}$ matches well with the observed surface variability in the $\mathrm{NH}$, indicating surface variability is driven largely by STE flux. 
491
A major surprise from our model is that the STE flux of $\mathrm{O}_{3}$ is predominantly $\mathrm{NH}$ biased currently because of the Antarctic ozone hole. Prior to 1980, and after 2060, it would/will be symmetric between the hemispheres. Our model calculates slightly greater STE fluxes for trace gases like $\mathrm{N}_{2} \mathrm{O}$ or $\mathrm{F} 11$ in the $\mathrm{SH}$, which is counter to prevailing theory that the wave-driven fluxes force relatively greater STE in the $\mathrm{NH}$. This difference cannot be directly tested with observations of trace gases, but a range of $\mathrm{N}_{2} \mathrm{O}$ hemispheric observations are well modeled and support this premise. More extensive work with multi-model ensembles that include both chemical and dynamical diagnostics in the stratosphere would be needed to overturn the established theory. Our work reemphasizes the importance of trace-gas correlations in the lowermost stratosphere as a key observational metric for climate models that may be able to constrain total STE fluxes. The tracer slopes may go beyond just relative STE fluxes because we have other measurements from the upper stratosphere to the surface that constrain, for example, the absolute flux of $\mathrm{N}_{2} \mathrm{O}$ better than we first did using just the modeled lifetime (Murphy \& Fahey, 1994; McLinden et al., 2000).

In Table 1, we propose a set of observation-based model metrics that relate to STE fluxes and will help the community build more robust models to better derive the STE flux of $\mathrm{O}_{3}$.

\begin{tabular}{|c|c|c|c|c|}
\hline Name & Metric & Measured values & Model requirements & Example figure \\
\hline $\mathrm{N}_{2} \mathrm{O}$ loss & $\begin{array}{l}\text { Annual and QBO } \\
\text { cycles of global } \\
\text { mean stratospheric } \\
\mathrm{N}_{2} \mathrm{O} \text { loss }\end{array}$ & $\begin{array}{l}\text { Monthly } \mathrm{N}_{2} \mathrm{O} \text { loss } \\
\text { calculated from } \\
\text { MLS profiles } \\
\text { (2005-present) }\end{array}$ & $\begin{array}{l}\text { Stratospheric } \\
\text { chemistry for } \mathrm{N}_{2} \mathrm{O} \text { as } \\
\text { tracer; a QBO cycle; } \\
\text { monthly mean } \\
\text { diagnostics }\end{array}$ & $\begin{array}{l}\text { Fig. } 4 \text { (P2015); } \\
\text { Fig. } 2 \text { (R2021); } \\
\text { Fig. } 3 \text { (R2022) }\end{array}$ \\
\hline $\begin{array}{l}\text { STE } \\
\text { slopes }\end{array}$ & $\begin{array}{l}\text { Matching } \mathrm{O}_{3}: \mathrm{N}_{2} \mathrm{O} \\
\text { slopes in } \\
\text { lowermost } \\
\text { stratosphere }\end{array}$ & $\begin{array}{l}\text { ACE FTS profiles } \\
\text { (2004-2013) }\end{array}$ & $\begin{array}{l}\text { Stratospheric } \mathrm{O}_{3} \text { and } \\
\mathrm{N}_{2} \mathrm{O} \text { calculation, } \\
\text { possibly also CFCs; } \\
\text { monthly snapshots }\end{array}$ & Fig. 7 (R2022) \\
\hline $\begin{array}{l}\text { Strat } \mathrm{O}_{3} \\
\text { column }\end{array}$ & $\begin{array}{l}\text { Annual and QBO } \\
\text { composite cycles } \\
\text { of stratospheric } \mathrm{O}_{3} \\
\text { column }\end{array}$ & $\begin{array}{l}\text { Monthly zonal } \\
\text { mean } \\
\text { stratospheric O3 } \\
\text { column from } \\
\text { Z2019 analysis } \\
\text { (2005-present) }\end{array}$ & $\begin{array}{l}\text { Stratospheric } \mathrm{O}_{3} \\
\text { chemistry; a QBO } \\
\text { cycle; monthly mean } \\
\text { diagnostics; separate } \\
\text { strat \& trop } \mathrm{O}_{3} \\
\text { columns }\end{array}$ & Fig. 9 (R2022) \\
\hline \multirow[t]{2}{*}{$\begin{array}{l}\mathrm{N}_{2} \mathrm{O} \text { loss } \\
\text { at surface }\end{array}$} & $\begin{array}{l}\text { Annual and QBO } \\
\text { composite cycles } \\
\text { of surface } \mathrm{N}_{2} \mathrm{O} \\
\text { solely from } \\
\text { stratospheric loss }\end{array}$ & $\begin{array}{l}\text { NOAA surface } \\
\mathrm{N}_{2} \mathrm{O} \text { observations }\end{array}$ & $\begin{array}{l}\text { Stratospheric } \mathrm{N}_{2} \mathrm{O} \\
\text { chemistry; } \mathrm{N} 2 \mathrm{OX} \text { as } \\
\text { a tracer; monthly } \\
\text { mean diagnostics }\end{array}$ & $\begin{array}{l}\text { Fig. } 3 \text { (R2021); } \\
\text { Fig. } 5 \text { (R2022) }\end{array}$ \\
\hline & & $\begin{array}{l}\text { Constrained } \\
\text { (modeled) values }\end{array}$ & & \\
\hline $\begin{array}{l}\text { STE flux } \\
\text { of } \mathrm{O}_{3}\end{array}$ & - & $\begin{array}{c}\text { Monthly, latitude } \\
\text { or hemispheric }\end{array}$ & $\begin{array}{l}\text { Run O3strat as a } \\
\text { tracer; diagnose }\end{array}$ & $\begin{array}{l}\text { Fig. } 1 \& 2 \\
(\text { R2022) }\end{array}$ \\
\hline
\end{tabular}




\begin{tabular}{|c|c|c|c|c|}
\hline & & $\begin{array}{l}\text { resolved, net } \mathrm{O}_{3} \\
\text { flux }\end{array}$ & $\begin{array}{l}\text { monthly flux into } \\
\text { troposphere, at } \\
\text { tropopause or through } \\
\text { trop- loss of O3strat }\end{array}$ & \\
\hline \begin{tabular}{|l|} 
STE flux \\
of $\mathrm{N}_{2} \mathrm{O}$ \\
depleted \\
air (also \\
CFC-11) \\
\end{tabular} & - & $\begin{array}{l}\text { Monthly, latitude } \\
\text { or hemispheric } \\
\text { resolved, STE } \\
\text { flux of } \mathrm{N}_{2} \mathrm{O} \\
(\mathrm{CFC}-11)\end{array}$ & $\begin{array}{l}\text { Run cN2O (cF11) as } \\
\text { a tracer; diagnose } \\
\text { monthly flux into } \\
\text { troposphere }\end{array}$ & $\begin{array}{l}\text { Fig. 1 \& } 2 \\
\text { (R2022); }\end{array}$ \\
\hline $\begin{array}{l}\mathrm{SH} \mathrm{O}_{3} \\
\text { hole and } \\
\text { flux }\end{array}$ & - & $\begin{array}{l}\text { Change in } \mathrm{SH} \mathrm{O}_{3} \\
\text { STE flux with } \\
\text { size of ozone } \\
\text { hole; observed } \\
\text { IAV of } \mathrm{O}_{3} \text { hole }\end{array}$ & $\begin{array}{l}\text { IAV of ozone hole; } \\
\text { daily total } \mathrm{O}_{3} \text { column } \\
\text { (lat, long); monthly } \\
\mathrm{SH} \mathrm{O}_{3} \text { STE flux }\end{array}$ & Fig 7 (R2022) \\
\hline
\end{tabular}

Notes: Constrained values are key, model-only, derived quantities that can be diagnosed from CCMs or CTMs. Reference shorthand: P2015 = Prather et al., 2015; R2021 = Ruiz et al., 2021; R2022 = this paper; Z2019 = Ziemke et al., 2019

\section{Author Contributions:}

DJR and MJP designed and carried out the study and prepared the manuscript for publication.

\section{Competing interests:}

The authors declare that they have no conflict of interest.

\section{Acknowledgments:}

Research at UCI was supported by grants from the National Aeronautics and Space Administration's Modeling, Analysis and Prediction Program (award NNX13AL12G), and Atmospheric Chemistry Modeling and Analysis Program (80NSSC20K1237, NNX15AE35G), and the National Science Foundation (NRT-1633631). We gratefully acknowledge the work of the MLS team in producing the Level 3 data sets that enabled our MLS-related analyses. Work at the Jet Propulsion Laboratory, California Institute of Technology, was performed under contract with the National Aeronautics and Space Administration. We thank the ACE-FTS team for making the climatology data used here available for our analyses. The Atmospheric Chemistry Experiment (ACE), also known as SCISAT, is a Canadian-led mission mainly supported by the Canadian Space Agency. We also acknowledge Ed Dlugokencky for providing the surface $\mathrm{N}_{2} \mathrm{O}$ data that was used here to produce an observation-based reference with which to compare our simulated results. The data used to produce the figures and tables in this work are accessible via the DRYAD repository with DOI https://doi.org/10.7280/D1JX0K 


\section{References:}

Appenzeller, C., Holton, J. R., \& Rosenlof, K. H. (1996). Seasonal variation of mass transport across the tropopause. Journal of Geophysical Research Atmospheres, 101(D10), 1507115078. https://doi.org/10.1029/96JD00821

Baldwin, M. P., Gray, L. J., Dunkerton, T. J., Hamilton, K., Haynes, P. H., Holton, J. R., et al. (2001). The Quasi-Biennial Oscillation. Reviews of Geophysics, (1999).

Coy, L., Newman, P. A., Pawson, S., \& Lait, L. R. (2017). Dynamics of the disrupted 2015/16 quasi-biennial oscillation. Journal of Climate, 30(15), 5661-5674. https://doi.org/10.1175/JCLI-D-16-0663.1

Dlugokencky, E.J., A.M. Crotwell, J.W. Mund, M. J. C., \& Thoning, K. W. (2019). Atmospheric Nitrous Oxide Dry Air Mole Fractions from the NOAA ESRL Carbon Cycle Cooperative Global Air Sampling Network, 1997-2018, Version: 2019-07. https://doi.org/10.15138/53g1-x417

Gettleman, A., Holton, J. R., \& Rosenlof, H. (1997). Mass fluxes of O3, CH4, N2O and CF2Cl2 in the lower stratosphere calculated from observational data. Journal of Geophysical Research, 102(97).

Hamilton, K., \& Fan, S. M. (2000). Effects of the stratospheric quasi-biennial oscillation onlong-lived greenhouse gases in the troposphere. Journal of Geophysical Research Atmospheres, 105(D16), 20581-20587. https://doi.org/10.1029/2000JD900331

Hirsch, A. I., Michalak, A. M., Bruhwiler, L. M., Peters, W., Dlugokencky, E. J., \& Tans, P. P. (2006). Inverse modeling estimates of the global nitrous oxide surface flux from 1998-2001. Global Biogeochemical Cycles, 20(1), 1-17. https://doi.org/10.1029/2004GB002443

Holton, J. R. (1990). On the Global Exchange of Mass between the Stratosphere and Troposphere. Journal of the Atmospheric Sciences, 47(3), 392-395. https://doi.org/10.1175/1520-0469(1990)047<0392:OTGEOM>2.0.CO;2

Holton, J. R., Haynes, P. H., McIntyre, M. E., Douglass, A. R., Rood, R. B., \& Pfischer, L. (1995). Stratosphere-Troposphere Exchange. Reviews of Geophysics, 33(4), 403-439.

Hsu, J., \& Prather, M. J. (2009). Stratospheric variability and tropospheric ozone. Journal of Geophysical Research Atmospheres, 114(6), 1-15. https://doi.org/10.1029/2008JD010942

Hsu, J., \& Prather, M. J. (2010). Global long-lived chemical modes excited in a 3-D chemistry transport model: Stratospheric N2O, NOy, O3 and CH 4 chemistry. Geophysical Research Letters, 37(7), 1-5. https://doi.org/10.1029/2009GL042243

Hsu, J., \& Prather, M. J. (2014). Is the residual vertical velocity a good proxy for stratospheretroposphere exchange of ozone? Geophysical Research Letters, 41(24), 9024-9032. https://doi.org/10.1002/2014GL061994

Hsu, J., Prather, M. J., \& Wild, O. (2005). Diagnosing the stratosphere-to-troposphere flux of ozone in a chemistry transport model. Journal of Geophysical Research D: Atmospheres, 110(19), 1-12. https://doi.org/10.1029/2005JD006045

Isaksen, I. S. A., Zerefos, C., Wang, W. C., Balis, D., Eleftheratos, K., Rognerud, B., et al. (2012). Attribution of the Arctic ozone column deficit in March 2011. Geophysical Research Letters, 39(24), 6-10. https://doi.org/10.1029/2012GL053876 
Kinnersley, J. S., \& Tung, K. K. (1999). Mechanisms for the extratropical QBO in circulation and ozone. Journal of the Atmospheric Sciences, 56(12), 1942-1962. https://doi.org/10.1175/1520-0469(1999)056<1942:MFTEQI>2.0.CO;2

Koo, J. H., Walker, K. A., Jones, A., Sheese, P. E., Boone, C. D., Bernath, P. F., \& Manney, G. L. (2017). Global climatology based on the ACE-FTS version 3.5 dataset: Addition of mesospheric levels and carbon-containing species in the UTLS. Journal of Quantitative Spectroscopy and Radiative Transfer, 186, 52-62. https://doi.org/10.1016/j.jqsrt.2016.07.003

Liang, Y., Gillett, N. P., \& Monahan, A. H. (2020). Climate Model Projections of 21st Century Global Warming Constrained Using the Observed Warming Trend. Geophysical Research Letters, 47(12), 1-10. https://doi.org/10.1029/2019GL086757

Liu, H., Considine, D. B., Horowitz, L. W., Crawford, J. H., Rodriguez, J. M., Strahan, S. E., et al. (2016). Using beryllium-7 to assess cross-tropopause transport in global models. Atmospheric Chemistry and Physics, 16(7), 4641-4659. https://doi.org/10.5194/acp-164641-2016

Manney, G. L., Santee, M. L., Rex, M., Livesey, N. J., Pitts, M. C., Veefkind, P., et al. (2011). Unprecedented Arctic ozone loss in 2011. Nature, 478(7370), 469-475. https://doi.org/10.1038/nature10556

McLinden, C. A., Olsen, S. C., Hannegan, B., Wild, O., Prather, M. J., \& Sundet, J. (2000). Stratospheric ozone in 3-D models: A simple chemistry and the cross-tropopause flux. Journal of Geophysical Research Atmospheres, 105(D11), 14653-14665. https://doi.org/10.1029/2000JD900124

Montzka, S. A., Dutton, G. S., Yu, P., Ray, E., Robert, W., Daniel, J. S., et al. (2018). An unexpected and persistent increase in global emissions of ozone-depleting CFC-11. Nature.

Murphy, D. M., \& Fahey, D. W. (1994). An estimate of the flux of stratospheric reactive nitrogen and ozone into the troposphere. Journal of Geophysical Research, 99(D3), 5325. https://doi.org/10.1029/93JD03558

Nevison, C. D., Kinnison, D. E., \& Weiss, R. F. (2004). Stratospheric influences on the tropospheric seasonal cycles of nitrous oxide and chlorofluorocarbons. Geophysical Research Letters, 31(20), 1-5. https://doi.org/10.1029/2004GL020398

Nevison, Cynthia D., Mahowald, N. M., Weiss, R. F., \& Prinn, R. G. (2007). Interannual and seasonal variability in atmospheric N2O. Global Biogeochemical Cycles, 21(3), 1-13. https://doi.org/10.1029/2006GB002755

Newman, P., Coy, L., Pawson, S., \& Lait, L. R. (2016). The anomalous change in the QBO in 2015-2016. Geophysical Research Letters, 43(16), 8791-8797. https://doi.org/10.1002/2016GL070373

Newman, Paul. (2020). The Quasi-biennial Oscillation (QBO). Retrieved from https://acdext.gsfc.nasa.gov/Data_services/met/qbo/qbo.html

Olsen, M. A., Schoeberl, M. R., \& Douglass, A. R. (2004). Stratosphere-troposphere exchange of mass and ozone. Journal of Geophysical Research D: Atmospheres, 109(24), 1-10. https://doi.org/10.1029/2004JD005186

Olsen, M. A., Manney, G. L., \& Liu, J. (2019). The ENSO and QBO Impact on Ozone Variability and Stratosphere-Troposphere Exchange Relative to the Subtropical Jets. Journal of Geophysical Research: Atmospheres, 124(13), 7379-7392. https://doi.org/10.1029/2019JD030435

Olsen, S. C., McLinden, C. A., \& Prather, M. J. (2001). Stratospheric N 2 O-NO y system: 
Testing uncertainties in a three-dimensional framework. Journal of Geophysical Research: Atmospheres, 106(D22), 28771-28784. https://doi.org/10.1029/2001JD000559 (2016). An unexpected disruption of the atmospheric quasi-biennial oscillation. Science, 353(6306), 1424-1427. https://doi.org/10.1126/science.aah4156

Plumb, R. A., \& Ko, M. K. W. (1992). Interrelationships between mixing ratios of long-lived stratospheric constituents. Journal of Geophysical Research: Atmospheres, 97(D9), 1014510156. https://doi.org/10.1029/92JD00450

Prather, M. J., Hsu, J., Deluca, N. M., Jackman, C. H., Oman, L. D., Douglass, A. R., et al. (2015). Measuring and modeling the lifetime of nitrous oxide including its variability. Journal of Geophysical Research : Atmospheres, 1-13. https://doi.org/10.1002/2015JD023267.Received

Prather, M. J., Zhu, X., Flynn, C. M., Strode, S. A., Rodriguez, J. M., Steenrod, S. D., et al. (2017). Global atmospheric chemistry - Which air matters. Atmospheric Chemistry and Physics, 17(14), 9081-9102. https://doi.org/10.5194/acp-17-9081-2017

Ray, E. A., Portmann, R. W., Yu, P., Daniel, J., Montzka, S. A., Dutton, G. S., et al. (2020). The influence of the stratospheric Quasi-Biennial Oscillation on trace gas levels at the Earth's surface. Nature Geoscience, 13(1), 22-27. https://doi.org/10.1038/s41561-019-0507-3

Ruiz, D. J., Prather, M. J., Strahan, S. E., Thompson, R. L., Froidevaux, L., \& Steenrod, S. D. (2021). How Atmospheric Chemistry and Transport Drive Surface Variability of N 2 O and CFC-11 . Journal of Geophysical Research: Atmospheres, 126(8), 1-16. https://doi.org/10.1029/2020jd033979

Stohl, A., Bonasoni, P., Cristofanelli, P., Collins, W., Feichter, J., Frank, A., et al. (2003). Stratosphere-troposphere exchange: A review, and what we have learned from STACCATO. Journal of Geophysical Research Atmospheres, 108(12). https://doi.org/10.1029/2002jd002490

Strahan, S. E., Douglass, A. R., Stolarski, R. S., Akiyoshi, H., Bekki, S., Braesicke, P., et al. (2011). Using transport diagnostics to understand chemistry climate model ozone simulations. Journal of Geophysical Research Atmospheres, 116(17), 1-18. https://doi.org/10.1029/2010JD015360

Strahan, S. E., Oman, L. D., Douglass, A. R., \& Coy, L. (2015). Modulation of Antarctic vortex composition by the quasi-biennial oscillation. Geophysical Research Letters, 42(10), 42164223. https://doi.org/10.1002/2015GL063759

Tang, Q., Hess, P. G., Brown-Steiner, B., \& Kinnison, D. E. (2013). Tropospheric ozone decrease due to the Mount Pinatubo eruption: Reduced stratospheric influx. Geophysical Research Letters, 40(20), 5553-5558. https://doi.org/10.1002/2013GL056563

Tang, Q., Prather, M. J., Hsu, J., Ruiz, D. J., Cameron-Smith, P. J., Xie, S., \& Golaz, J. C. (2021). Evaluation of the interactive stratospheric ozone (O3v2) module in the E3SM version 1 Earth system model. Geoscientific Model Development, 14(3), 1219-1236. https://doi.org/10.5194/gmd-14-1219-2021

Thompson, R. L., Chevallier, F., Crotwell, A. M., Dutton, G., Langenfelds, R. L., Prinn, R. G., et al. (2014). Nitrous oxide emissions 1999 to 2009 from a global atmospheric inversion. Atmospheric Chemistry and Physics, 14(4), 1801-1817. https://doi.org/10.5194/acp-141801-2014 
Tian, H., Xu, R., Canadell, J. G., Thompson, R. L., Winiwarter, W., Suntharalingam, P., et al. (2020). A comprehensive quantification of global nitrous oxide sources and sinks. Nature, 586(7828), 248-256. https://doi.org/10.1038/s41586-020-2780-0

Tokarska, K. B., Stolpe, M. B., Sippel, S., Fischer, E. M., Smith, C. J., Lehner, F., \& Knutti, R. (2020). Past warming trend constrains future warming in CMIP6 models. Science Advances, 6(12), 1-14. https://doi.org/10.1126/sciadv.aaz9549

Tung, K. K., \& Yang, H. (1994). Global QBO in Circulation and Ozone. Part II: A Simple Mechanistic Model. Journal of the Atmospheric Sciences, 51(19), 2708-2721. https://doi.org/10.1175/1520-0469(1994)051<2708:GQICAO>2.0.CO;2

Yang, H., Chen, G., Tang, Q., \& Hess, P. (2016). Quantifying isentropic stratospheretroposphere exchange of ozone. Journal of Geophysical Research, 121(7), 3372-3387. https://doi.org/10.1002/2015JD024180

Young, P. J., Archibald, A. T., Bowman, K. W., Lamarque, J.-F., Naik, V., Stevenson, D. S., et al. (2013). Pre-industrial to end 21st century projections of tropospheric ozone from the Atmospheric Chemistry and Climate Model Intercomparison Project (ACCMIP). Atmospheric Chemistry and Physics, 13(4), 2063-2090. https://doi.org/10.5194/acp-132063-2013

Young, P. J., Naik, V., Fiore, A. M., Gaudel, A., Guo, J., Lin, M. Y., et al. (2018). Tropospheric ozone assessment report: Assessment of global-scale model performance for global and regional ozone distributions, variability, and trends. Elementa, 6 . https://doi.org/10.1525/elementa.265

Ziemke, J. R., Oman, L. D., Strode, S. A., Douglass, A. R., Olsen, M. A., McPeters, R. D., et al. (2019). Trends in global tropospheric ozone inferred from a composite record of TOMS/OMI/MLS/OMPS satellite measurements and the MERRA-2 GMI simulation. Atmospheric Chemistry and Physics, 19(5), 3257-3269. https://doi.org/10.5194/acp-193257-2019 